\title{
Neurological features of children with food allergies
}

\author{
Sam Lingam \\ From Food Allergy and Anaphylaxis Meeting 2011 \\ Venice, Italy. 17-19 February 2011
}

Food allergy is a multisystem disorder. It presents with various neurological manifestations.

In a clinical study of 25 children attending a food allergy clinic the following neurological features were detected:

Irritability 25 (100\%)

Behaviour problem18 (72\%)

Hyperactivity 16 (64\%)

Migraine 13 (52\%)

Fatigue 13 (52\%)

Clumsiness 4 (16\%)

Over the years clinical practice also showed that the diagnosis of food allergy and appropriate management gives excellent symptom relief with tremendous job satisfaction. Parents appreciate the diagnosis and management when symptoms improve.

Recalcitrant eczema and hyperactivity in children could be due to food allergies. Abnormalities of behaviors and mood are not all in the mind; it can be improved by dietary manipulation.

\section{Conclusion}

Food allergy is here to stay; clinicians should make the diagnosis by appropriate history, examination looking for clinical features and behaviour phenotypes and by investigations. A paediatric history questionnaire is helpful in obtaining the detailed allergy history. The questionnaire will be circulated to participants with the handout.

Published: 12 August 2011

Harley Street Paediartic Chambers, London, UK
doi:10.1186/2045-7022-1-S1-P85

Cite this article as: Lingam: Neurological features of children with food allergies. Clinical and Translational Allergy 2011 1(Suppl 1):P85.
Submit your next manuscript to BioMed Central and take full advantage of:

- Convenient online submission

- Thorough peer review

- No space constraints or color figure charges

- Immediate publication on acceptance

- Inclusion in PubMed, CAS, Scopus and Google Scholar

- Research which is freely available for redistribution

Submit your manuscript at www.biomedcentral.com/submit

\section{() Biomed Central}

\section{() Biomed Central}

(C) 2011 Lingam; licensee BioMed Central Ltd. This is an open access article distributed under the terms of the Creative Commons Attribution License (http://creativecommons.org/licenses/by/2.0), which permits unrestricted use, distribution, and reproduction in any medium, provided the original work is properly cited. 